\title{
Productivity and Export Growth in the South African Manufacturing Sector ${ }^{1}$
}

\section{Larette van Rensburg and Willem Naudé}

\section{School of Economics, Money \& Banking, Potchefstroom University for CHE}

\begin{abstract}
This paper empirically investigates the direction of causality between export and productivity growth in 22 South African manufacturing industries. Data spanning the period 1972 to 1993 are used. Standard Granger-causality tests are complemented by cointegration analyses and the estimation of a theoretically derived regression model. Bearing in mind methodology difficulties caused by inadequate data, little evidence of a statistically significant relationship between export growth and productivity growth is found. Only in case of the chemicals and wood processing sectors were statistically significant evidence found that export expansion could cause an increase in productivity. Domestic demand expansion was found to be a possibly more significant determinant of productivity increases.
\end{abstract}

JEL F 43

\section{INTRODUCTION}

It is often claimed that there exist a positive association between export growth and economic growth (e.g. Kavoussi, 1984). In the literature the view is that export growth will cause economic growth (Edwards, 1992). The case for this particular causal direction can be explained as follows. First, an increase in exports may allow an increase in imported capital goods, which raises the growth rate of capital formation and thus stimulates productivity of labour and capital, leading to output growth (Islam, 1998: 416). Second, export-oriented industries, particularly in manufacturing, are argued to be more susceptible to productivity improvements (due to exposure to competition and foreign technology transfers) and these lead to more investment, scale-benefits and more rapid output growth (Levine \& Renelt, 1992: 943). Productivity growth is thus seen as central in the causality chain from export growth to output growth. Kavoussi (1984: 241) states that a reason for the positive association between export and economic growth is due to "a favourable impact of exports on total factor productivity". 
Cross-country studies generally support the existence of a positive association between export and output growth. However, individual country studies based on time-series data tend to produce ambiguous results ${ }^{2}$ (Fajana, 1979; Goncalves \& Richtering, 1987). Recently Chand (1998: 15) even goes as far as to maintain that "the link between trade, trade policy and economic growth remains an open question". Problematic in these studies is the issue of whether the associations found may be interpreted as a sign of causation between export growth and economic growth, since a significant correlation between variables does not necessarily imply that the one causes the other (Jung \& Marshall, 1985; Hsiao, 1987; Chow, 1987).

In South Africa, the direction of causality between export growth and economic growth may be important due to the declared intention of the new government to pursue an export-led growth path (GEAR, 1996). A key strategy to achieve high export growth in South Africa is the emphasis in trade and industrial policy on opening up the economy through trade liberalisation (Coetzee, et al, 1997). Various incentive programmes have been introduced to stimulate exports especially of manufactured goods (see the appendix).

If the direction of causality between export and output growth in South Africa is indeed from export to output, then the above policy emphasis may be justified. However, if causality runs in the opposite direction, other measures which could raise economic growth may be more appropriately emphasised over the short and medium term. Examples of these could include labour market policies and restructuring, govemment expenditure and taxation policies, and selective import protection (see also Bell \& Cattaneo, 1998).

It is the purpose of this paper to investigate the direction of causality between export growth and output growth. Given the fact that South Africa's trade liberalisation programme is relatively recent, being implemented in accordance with the Uruguay Round of the GATT from January 1995, it may be to soon to pick up statistically significant effects of higher export growth on output growth from official data. The theoretical justification for the direction of causality from export growth to output growth implies a time-lag since higher export growth must first result in higher total factor productivity as a precondition for sustained higher output growth ${ }^{3}$. Therefore, to be able to obtain preliminary indications as to the direction of causality between export growth and output growth, this paper will focus on the relationship between exports and productivity. Due to the prominence of the manufacturing sector in the tradable sectors of the economy, the relative stability of output prices, and the significant removal of trade protection measures from this sector, manufacturing data on the 25 main manufacturing sectors will be used. The use of data from the manufacturing sector is appropriate given Kavoussi's (1984: 247) finding that the impact of 
exports from the manufacturing sector on total factor productivity is greater than that of primary exports. He states that "among middle-income countries (such as South Africa), gains from export expansion are significant only in those economies that shift to exports of manufactured products".

\section{EXPORTS AND PRODUCTIVITY}

The proposal that exports may raise productivity (i.e. that causality runs predominantly from exports to productivity) is a departure from the standard, neo-classical trade theory. In the neo-classical trade theory - specifically the comparative cost theory associated at first with David Ricardo, labour productivity is treated as exogenous. In the comparative cost theory, each country will have a comparative advantage and will export those commodities for which its relative output per worker exceeds its relative money wage in that particular industry (i.e. where it has a particular productivity advantage). In this theory, the association between productivity and exports is clear: only those goods in which a country has more productive labour, will exports be successful (Harberler, 1937).

In reality, productivity is affected by a host of factors, such as R\&D, innovation, accumulation of physical and human capital, infrastructure, economies of scale, market structure, demographic change, and the introduction of new technology (Yadavalli, 1998b: 8). More recently the economic literature have begun arguing that most of these factors are influenced by a country's trade regime and degree of openness to international trade.

The recent view in economic theory, inspired by the endogenous or "new" growth literature, is that higher exports may raise productivity (Kunst and Marin, 1989: 699-700). Endogenous growth theory departs significantly from the assumptions of the classical and neo-classical growth theories with respect to growth and trade, specifically with respect to the endogeneity of productivity. Productivity growth is associated with increasing returns to scale, learning-bydoing (LBD) and "spill-over" effects of export expansion (Grossman \& Helpman, 1990; Lucas, 1988; 1990; Romer, 1986; 1990).

Regarding the positive impact of exports on productivity, the following related arguments can be put forward in justification (Bhagwati, 1978; Kavoussi, 1984):

First, exports may facilitate the allocation (or re-allocation) of investment in the most efficient and competitive sectors of an economy. Increasing specialisation in export-oriented sectors may stimulate productivity in those sectors (Emery, 1967: 471; Piazollo \& Wurth, 1995). 
Second, higher export growth may enable manufacturing firms to achieve economies of scale because they now have access to international markets - not only domestic markets - and can thus make larger scale operations profitable (Grossman \& Helpman, 1901: 243).

Third, increased international competitiveness due to exporting onto global markets may increase the pressure on export-oriented industries to keep costs relative to outputs low (Teitel \& Thoumi, 1986; 466). The latter may create incentives for the introduction of technological change which improves productivity (Geroski, 1989: 577).

Fourth, the growth of exports may be seen to have a positive influence on productivity of the whole economy of a country via externalities of exports on other sectors (Bhagwati, 1978: 213).

Fifth, foreign contributions to the local stock of knowledge increase with the number of commercial transactions between domestic and foreign agents (Grossman \& Helpman, 1990: 168).

Six, an increase in exports may permit a relaxation in a country's balance of payments constraint, which facilitates domestic growth through improved availability of essential imports (Teitel \& Thoumi, 1986: 469).

Within recent "endogenous" growth theories the view has however also been put forward that the direction of causality may not be from exports to productivity, but rather the other way around. Piazollo and Wurth (1992:272) describe these as technology theories of trade and/or "new" infant industry arguments. Krugman (1984) and Rodrik (1988) for instance, states that import protection may cause productivity gains by allowing domestic sales to expand. In this regard Krugman (1984) shows that under a oligopolistic market structure with Cournot behaviour import protection can lead to productivity gains which stimulate export expansion. According to this argument import protection may lead to productivity gains by allowing domestic sales to expand. Import protection may thus under certain market conditions act as an export promotion policy.

Abeysinghe and Yeok (1998) provide empirical evidence that import protection and the related or implied policy of exchange rate overvaluation has stimulated productivity and export growth in Singapore. Teitel and Thoumi (1986) found empirical evidence that import protection may have stimulated productivity in certain industries in Brazil and Argentina. More particularly, they claim that the direction of causality runs from import protection to industrial "maturity" to higher productivity to higher exports." They also perform back-of-the-envelope 
calculations to show that average annual growth rates of $4.14 \%$ in total factor productivity (TFP) would be needed if infant industries in developing countries are to eliminate a $50 \%$ cost disadvantage relative to developed countries industries over ten years (Teitel and Thoumi, 1986: 465).

More recently theories of intra-industry trade have emphasised a bi-directional causality between exports and productivity (Piazollo \& Wurth, 1992: 273). In these theories greater trade (exports) changes a country's market structure towards fewer firms, more concentrated declining cost industries and a larger proportion of resources in declining cost industries (Helpman \& Krugman, $1985 ; 1989$ ).

\section{PRODUCTIVITY AND EXPORTS IN SOUTH AFRICA'S MANUFACTURING SECTOR}

\subsection{Summary Statistics}

Tables 1 and 2 below summarise the salient features of productivity and export growth in South Africa's manufacturing sector. In Table 1, the situation between 1972 and 1990 is summarised. Table 2 summarises the situation between 1990 and 1996. The year 1990 has been selected as a cut-off date since the subsequent period represents South Africa's reintegration into the international community.

Table 1 Output, Productivity and Exports in Manufacturing, 1972 1990, (Average Annual Growth \%)

\begin{tabular}{|l|c|c|c|c|}
\hline \multicolumn{1}{|c|}{ Sector } & Output & MFP & $\begin{array}{c}\text { Export/ } \\
\text { Output (\%) }\end{array}$ & Exports \\
\hline Food & $2.6 \%$ & $-0.52 \%$ & $11.21 \%$ & $-1.13 \%$ \\
\hline Beverages & $7.2 \%$ & $2.33 \%$ & $3.26 \%$ & $8.53 \%$ \\
\hline Tobacco & $4.81 \%$ & $3.11 \%$ & $3.58 \%$ & $14.15 \%$ \\
\hline Textiles & $-0.31 \%$ & $-1.10 \%$ & $12.8 \%$ & $2.49 \%$ \\
\hline Clothing & $3.96 \%$ & $2.06 \%$ & $10.28 \%$ & $3.07 \%$ \\
\hline Leather Products & $2.84 \%$ & $1.24 \%$ & $15.99 \%$ & $6.27 \%$ \\
\hline Footwear & $4.05 \%$ & $1.54 \%$ & $3.49 \%$ & $5.84 \%$ \\
\hline Wood and wood products & $1.87 \%$ & $0.53 \%$ & $7.95 \%$ & $11.45 \%$ \\
\hline Furniture & $2.99 \%$ & $1.63 \%$ & $2.59 \%$ & $15.07 \%$ \\
\hline Paper and Paper products & $4.6 \%$ & $0.48 \%$ & $8.87 \%$ & $4.77 \%$ \\
\hline Printing and publishing & $1.45 \%$ & $-1.31 \%$ & $1.40 \%$ & $-1.07 \%$ \\
\hline Chemical products & $3.85 \%$ & $-2.84 \%$ & $9.15 \%$ & $4.84 \%$ \\
\hline Rubber products & $6.11 \%$ & $5.48 \%$ & $3.99 \%$ & $4.78 \%$ \\
\hline
\end{tabular}


Table 1 continued

\begin{tabular}{|l|c|c|c|c|}
\hline \multicolumn{1}{|c|}{ Sector } & Output & MFP & $\begin{array}{c}\text { Export/Out- } \\
\text { put (\%) }\end{array}$ & Exports \\
\hline Plastic products & $8.65 \%$ & $3.33 \%$ & $1.18 \%$ & $6.33 \%$ \\
\hline Glass and glass products & $4.85 \%$ & $0.43 \%$ & $5.98 \%$ & $6.98 \%$ \\
\hline $\begin{array}{l}\text { Other non-metallic } \\
\text { mineral }\end{array}$ & $0.64 \%$ & $-0.97 \%$ & $6.18 \%$ & $1.83 \%$ \\
\hline $\begin{array}{l}\text { Iron and steel basic } \\
\text { industries }\end{array}$ & $1.58 \%$ & $-0.71 \%$ & $19.85 \%$ & $9.11 \%$ \\
\hline Non-ferrous metal basics & $0.55 \%$ & $1.33 \%$ & $27.41 \%$ & $8.72 \%$ \\
\hline Metal products & $-0.28 \%$ & $-1.83 \%$ & $4.65 \%$ & $0.77 \%$ \\
\hline Machinery & $2.8 \%$ & $-1.1 \%$ & $9.97 \%$ & $-0.58 \%$ \\
\hline Electrical machinery & $3.89 \%$ & $-0.23 \%$ & $3.69 \%$ & $5.27 \%$ \\
\hline Motor vehicles and parts & $2.87 \%$ & $0.38 \%$ & $2.51 \%$ & $7.55 \%$ \\
\hline
\end{tabular}

(Based on data obtained from the IDC's Sectoral Manufacturing Data Series)

Table 1 shows that rubber products, tobacco production, and plastic production showed the largest increases in multifactor productivity (MFP) growth over the period 1972-1990, in each case of above 3\% per annum. Some sectors, e.g. chemicals, metal products and textiles experience negative growth rates in MFP growth over the period. When the average export growth rates are considered, Table 1 shows that the fastest average export growth rates were experienced in the furniture (15\%), tobacco $(14 \%)$, wood and wood products $(11 \%)$ and iron and basic steel industries $(9 \%)$. The latter sector was also the sector with the highest proportion of exports in total sales (27\%) over the period. In the case of tobacco and furniture there would seem to be a strong positive association between export growth and productivity; however, the iron and basic steel industry achieved high export growth despite a negative growth in MFP.

Based on Table 1, the Spearman rank-order correlation coefficient between export growth and MFP growth was calculated. Its value of 0.60 would suggest that there is not a very strong statistical association between manufacturing industries that experienced rapid export growth and industries that experienced rapid productivity improvements.

Table 2 below show that between 1990 and 1995, the highest MFP growth was experienced by the textile and clothing industries, and the highest export growth by the clothing industry $(2.9 \%)$, paper and paper products $(11 \%)$, plastic products $(8 \%)$, and non-ferrous basic metal products $(4.7 \%)$. 
Table 2 Output, Productivity and Exports in Manufacturing, 1990 1995, (Average Annual Growth \%)

\begin{tabular}{|l|c|c|c|c|}
\hline \multicolumn{1}{|c|}{ Sector } & Output & MFP & $\begin{array}{c}\text { Export/Out- } \\
\text { put (\%) }\end{array}$ & $\begin{array}{c}\text { Exports } \\
\mathbf{( 1 9 9 0 - 9 3 )}\end{array}$ \\
\hline Food & $-0.93 \%$ & $-2.50 \%$ & $6.49 \%$ & $-1.28 \%$ \\
\hline Beverages & $-0.61 \%$ & $-6.19 \%$ & $4.52 \%$ & $1.76 \%$ \\
\hline Tobacco products & $-2.71 \%$ & $0.95 \%$ & $5.11 \%$ & $-12.90 \%$ \\
\hline Textiles & $-1.55 \%$ & $2.90 \%$ & $20.33 \%$ & $-4.35 \%$ \\
\hline Clothing & $2.35 \%$ & $2.50 \%$ & $7.39 \%$ & $2.94 \%$ \\
\hline Leather products & $1.23 \%$ & $-2.41 \%$ & $22.35 \%$ & $3.21 \%$ \\
\hline Footwear & $-3.32 \%$ & $-1.09 \%$ & $3.36 \%$ & $-3.20 \%$ \\
\hline Wood and wood products & $-0.17 \%$ & $-1.25 \%$ & $11.24 \%$ & $-3.14 \%$ \\
\hline Furniture & $-0.39 \%$ & $-1.94 \%$ & $7.30 \%$ & $2.77 \%$ \\
\hline Paper and paper products & $-2.12 \%$ & $-1.28 \%$ & $11.17 \%$ & $11.68 \%$ \\
\hline Printing and publishing & $-0.39 \%$ & $-3.29 \%$ & $.85 \%$ & $-14.9 \%$ \\
\hline Chemical products & $1.73 \%$ & $1.53 \%$ & $10.16 \%$ & $-3.13 \%$ \\
\hline Rubber products & $0.10 \%$ & $-3.25 \%$ & $4.93 \%$ & $0.15 \%$ \\
\hline Plastic products & $2.67 \%$ & $-3.99 \%$ & $1.82 \%$ & $8.45 \%$ \\
\hline Glass and glass products & $-1.09 \%$ & $-2.26 \%$ & $6.16 \%$ & $-7.59 \%$ \\
\hline $\begin{array}{l}\text { Other non - metallic } \\
\text { minerals }\end{array}$ & $-2.08 \%$ & $-0.48 \%$ & $7.95 \%$ & $1.13 \%$ \\
\hline $\begin{array}{l}\text { Iron and steel basic } \\
\text { industries }\end{array}$ & $-1.08 \%$ & $1.72 \%$ & $40.70 \%$ & $-0.75 \%$ \\
\hline Non- ferrous metal basic & $3.64 \%$ & $-9.93 \%$ & $40.99 \%$ & $4.71 \%$ \\
\hline Metal products & $-0.46 \%$ & $-0.73 \%$ & $6.91 \%$ & $2.29 \%$ \\
\hline Machinery & $-0.29 \%$ & $1.68 \%$ & $10.44 \%$ & $3.11 \%$ \\
\hline Electrical machinery & $-0.52 \%$ & $-4.99 \%$ & $6.58 \%$ & $6.79 \%$ \\
\hline $\begin{array}{l}\text { Motor vehicles and motor } \\
\text { vehicle parts }\end{array}$ & $0.55 \%$ & $-3.72 \%$ & $8.93 \%$ & $22.22 \%$ \\
\hline
\end{tabular}

Table 2 indicate that iron and basic steel, non-ferrous metal basic industries in particular increased their export share significantly - however in both these sectors productivity improvements was negligible. This could support the recent findings of lscan (1998: 123) based on a panel data study for Mexico, that trade liberalisation has a short-term beneficial impact on productivity growth rates (as firms that did not export previously now become more competitive and reap benefits from exports), but no significant long-term effect on productivity growth rates. 
Using the data in Table 2, the Spearman rank-order correlation coefficient between export growth and productivity growth between 1990 and 1993 was calculated. Over this period the correlation between export and productivity growth declined to 0.43 , suggesting the association between productivity and exports had weakened since 1990.

\subsection{Existing Empirical Findings for South Africa}

Existing studies into the relationship between trade policy and productivity, specifically exports and productivity, is largely lacking in South Africa. The only existing publicly available studies are those by Kohler and Holden (1992) and Piazollo and Wurth $(1992 ; 1995)$. These studies differ from the present study in that they are more concerned about the determinants of productivity and the relationship between trade liberalisation and output growth than with the direction of causality between exports and productivity.

Thus, although not explicitly testing for causality, Kohler and Holden (1992: 24) estimates a regression equation between South African manufacturing's relative export share and relative labour productivity. They find that "labour productivity appears to have been an insignificant determinant of export performance in South Africa's manufacturing industries".

Piazollo and Wurth (1992: 290) do not find strong evidence in favour of exportled growth in South Africa. Using standard Granger-causality tests on South African manufacturing between 1972 and 1990, they find that "in all but one of the manufacturing sectors economies of scale due to an increased domestic demand seems to be the main determinant for the productivity growth" (Piazollo \& Wurth, 1992: 290). Furthermore, they found that exports contributed positively to productivity growth in only 6 industries, namely

- Beverages

- Footwear

- Wood and wood products

- Other plastic products

- Other chemical products

- Glass and glass products

Piazollo and Wurth (1995) test for cointegration between total factor productivity (TFP) and production and TFP and exports using Johansen's (1988) maximum-likelihood method. They establish that in only eight cases are there indications of significant cointegration between the variables. This would suggest, generally, that exports and productivity are not cointegrated in South 
African manufacturing and that therefore there exists no stable long-run equilibrium relationship between exports and productivity as claimed in theory. Moreover, the results would imply that additional variables ought to be included in the cointegrating equation until a cointegration relationship be found - which would suggest that additional factors determines productivity growth and exports growth. Piazollo and Wurth (1995: 188) finds in this regard that "productivity development in South African manufacturing industries appears to be mainly due to domestic scale economies, as for 17 industries total production exerts a significantly positive influence on total factor productivity".

\section{DATA AND METHODOLOGY}

\subsection{Description of Data}

To test for the direction of causality between productivity and export growth in the manufacturing sector in South Africa, 22 main manufacturing sectors was chosen. The "other" sectors were omitted. These sectors are appropriate representatives of export-oriented industries in South Africa. Their various shares of exports in total output averaged between $0.8 \%$ in case of printing and publishing and $40 \%$ in case of iron and basic steel industries between 1990 and 1995 as can be seen from Table 2 above.

Annual data was obtained from the Industrial Development Corporation's (IDC) sectoral data series, spanning the period 1972 to 1993 , and from the National Productivity Institute (NPI) spanning the period 1960 to 1996. The lack of a longer timeframe remains a significant weakness of the present study.

The proxy for total factor productivity used in this paper is the IDC's and NPI's "multifactor productivity" variable. This has been obtained by dividing the production index of a sector by a weighed average of the labour and capital input indices. The latter are calculated by dividing the value-added index for a sector by its employment and fixed capital index.

The modelling framework used in this paper utilises firstly the concept of causality proposed by Granger (1969). Secondly, for those sectors where there is an indication that export growth affects productivity growth, an extended regression equation was estimated, following Okuda (1997).

\subsection{Granger Causality}

According to Granger's (1969) concept of causality, a variable, say total factor productivity in this case $\left(Z_{l}\right)$, is said to be "Granger-caused" by a variable, say 
exports $\left(X_{4}\right)$, if the information in past and present $X_{4}$ helps to improve the forecasts of the $Z_{1}$-variable (Judge et al, 1988: 768). Formally, $Z_{\mathrm{l}}$ will be Granger-caused by $X_{t}$ if for some period $t$ the following obtain:

$$
\sigma^{2}\left(Z_{i}(1) \mid \Omega_{i}\right)<\sigma^{2}\left(Z_{i}(1) \mid \Omega_{i} \backslash\left\{X_{s} \mid s \leq t\right\}\right)
$$

Where $\sigma^{2}=$ the conditional mean square error (MSE) of the optimal forecast of $Z_{1}(1)$ given the information in $\Omega_{1} ;$ Here $\Omega_{1} \backslash\left\{X_{s} \mid s \leq t\right\}$ on the right hand side of (1) denotes all information in $\Omega_{t}$ that is not in $\left\{X_{s} \mid s \leq t\right\}$.

It is standard to assume that $\left(Z_{l}, X_{l}\right)$ is generated by a stationary, normally distributed bivariate VAR with lag $p$ process that can be represented as

$\left[\begin{array}{l}Z_{1} \\ X_{t}\end{array}\right]=\left[\begin{array}{l}c_{1} \\ c_{2}\end{array}\right]+\left[\begin{array}{l}\alpha_{11,3} \alpha_{12,1} \\ \alpha_{21,1} \alpha_{22,1}\end{array}\right]\left[\begin{array}{c}Z_{t-1} \\ X_{t-1}^{\prime}\end{array}\right]+\ldots+\left[\begin{array}{l}\alpha_{11, p} \alpha_{12, p} \\ \alpha_{21, p} \alpha_{22, p}\end{array}\right]\left[\begin{array}{l}Z_{t-p} \\ X_{t-p}\end{array}\right]+\left[\begin{array}{l}\xi_{1} \\ \xi_{2 t}\end{array}\right]$

$X_{t}$ will not Granger-cause $Z_{t}$ if and only if

$$
\alpha_{12,1}=\alpha_{12,2}=\alpha_{12,3}=\ldots=\alpha_{12, p}=0
$$

and $Z_{t}$ will not Granger-cause $X_{t}$ if and only if

$$
\alpha_{21,1}=\alpha_{21,2}=\alpha_{21,3}=\ldots=\alpha_{21, p}=0
$$

Thus, in estimation of (2) the null hypotheses are of no Granger causality. These null hypotheses will be tested using a standard F-test to test the validity or otherwise of the imposition of the restrictions specified in (3) and (4).

A bivariate system such as this where $Z_{1}$ is caused by $X_{1}$ and $X_{1}$ is caused by $Z_{1}$ is called a feedback system.

The usual way to determine the appropriate lag length (p) in (2) is to use Akaike's Information Criterion (AIC) - see Akaike (1981). Following Piazollo and Wurth (1992: 300) however, the maximum lag length chosen here is 4 in order not to loose too many degrees of freedom.

\subsection{Cointegration Analysis}

Standard Granger-causality tests as described above are subject to a number of shortcomings (Judge et al,). If there would exist a stable Jong-run equilibrium 
relationship between variables so that they could be said to be cointegrated (see Engle and Granger, 1987) then an error-correction specification exists. In such an error-correction model, temporal causality can arise from two sources - nonzero coefficients of lagged change variables (which corresponds to standard Granger-causality tests) or through the error-correction terms. The standard Granger-causality tests typically omit to take these latter effects into consideration (see Miller \& Russek, 1990; Kalulumia \& Yourougou, 1998).

Granger (1986) and Engle \& Granger (1987) established that a vector of time series, all of which are stationary ${ }^{6}$ only after differencing, may have linear combinations which are stationary without differencing. In such case, those variables are cointegrated. The concept of cointegration provides justification for the use of error correction models (ECM's). In this paper cointegration analysis was carried out by using Engle \& Granger's two-stage modelling approach, whereby cointegration between variables is first achieved and the residuals from the cointegrating regression are used as a (stationary) levels term in the ECM.

\subsection{Extended Regressions}

One of the weaknesses of Granger-causality tests as described in 4.2 above is the lack of many relevant variables. For the sectors where there are an indication that export growth are significantly associated with productivity growth, the following equations was estimated, following Kouda (1997: 371).

$\Delta \ln T F P=\alpha_{0}+\alpha_{1} \Delta \ln K L_{t}+\alpha_{2} \Delta \ln E X P R O D_{t}+\alpha_{3} \Delta \ln P E N E_{t}+$ $\alpha_{4} \Delta \ln P R O D_{1}+e_{\text {, }}$

Where

TFP $=$ total factor productivity

$\mathrm{KL}=$ the factor intensity of a subsector, defined as the amount of capital per worker

EXPROD $=$ the export ratio, defined as the ratio of exports to total production $\mathrm{PENE}=$ the import penetration ratio, defined as imports/(production+importsexports)

PROD $=$ the total real production of a subsector

The above specification is intended to take into consideration such industrialisation-related variables as factor intensity, involvement in exports, and import liberalisation. Specifically, $\mathrm{KL}$ is included to capture the effect of capital 
intensification associated with the expected industrialisation of the South African economy. The variable PENE would measure the productivity impact of import liberalisation.

All estimations were done using either Microfit (version 3) and/or PC-GIVE 8.0 student version.

\section{RESULTS}

\subsection{Unit Root Tests}

Before estimating the equations presented in section 4 above, the various variables were subjected to tests for stationarity ${ }^{7}$. If in the above $Y_{1}$ is generated by the following first-order autoregressive (AR) process $Z_{1}=\rho Z_{1-1}+u_{1}$, then $Y_{1}$ will only be stationary if $|\rho|<1$. If $\rho=1$ then $Y_{\text {i }}$ will be non-stationary. A variable is stationary if it does not have a unit root. For instance, if the firstorder AR process generating $Y_{1}$ is re-written as $(1-\rho L) Z_{q}=u_{1}$, where $L$ is the lag operator then the characteristic equation is $(1-\rho L)=0$. In this case there is only one root $(L=1 / \rho)$ so that stationarity requires that $|\rho|<1$ (Harris, 1995: 18) It is problematic if non-stationary data is used in regression analysis, as it can lead to "spurious regressions" which occurs as inferences based on standard t- and Ftests are invalid in case of non-stationary data (see Banarjee, et al. 1993: 93-4). If a variable is non-stationary in its levels but stationary after first-differencing, it is said to contain one unit root in its levels and can be described as integrated of order one, denoted $\sim I(1)$. Correspondingly a stationary variable is denoted as being $-\mathrm{I}(0)$. More generally, a process is said to be integrated of order $d(\sim \mathrm{I}(d))$ if it needs to be differenced $d$-times to be stationary (Engle \& Granger, 1987:252).

Before econometrically estimating the relationship between productivity and export growth as described in section 4 above, the various productivity and export variables used for the 23 main manufacturing sectors were tested for stationarity. For this purpose use was made of the Augmented Dickey-Fuller (ADF) unit-root tests (see Dickey \& Fuller, 1981; Naudé, 1992). This test is a test based on the t-statistic on $\beta$ in equation (8):

$$
\Delta Y_{1}=\alpha+\mu t+\beta Y_{t-1}+\sum_{i=1}^{n} \gamma_{i} \Delta Y_{i+i}+u_{i}
$$

Where $n$ denotes the lag length. The null hypothesis is $H_{0}: \beta=0$, i.e. of unit root. Rejection of the null implies that $Y_{t}$ is $\sim(0)$, and failure to reject implies that $Y_{t}$ is non-stationary, i.e. $\sim \mathrm{I}(1)$. Critical values for the ADF (n) tests are given in MacKinnon (I991) and supplied with the PC-GIVE 8.0 software. 
The results of an ADF(4) test on multifactor productivity and exports in South Africa's manufacturing sector is summarised in Table 3 below.

Table 3 Augmented Dickey-Fuller Tests for Stationarity of Multifactor Productivity in South African Manufacturing

\begin{tabular}{|l|c|c|c|c|}
\hline \multicolumn{1}{|c|}{ Sector } & $\begin{array}{c}\text { Produc- } \\
\text { tivity levels }\end{array}$ & $\begin{array}{c}\text { Export- } \\
\text { levels }\end{array}$ & $\begin{array}{c}\text { Change in } \\
\text { productivity }\end{array}$ & $\begin{array}{c}\text { Change in } \\
\text { exports }\end{array}$ \\
\hline Food & 0.179 & -1.188 & -2.356 & -2.476 \\
\hline Beverages & -2.028 & 0.281 & -0.916 & -2.049 \\
\hline Tobacco Products & -1.676 & -1.190 & -1.959 & -1.934 \\
\hline Textiles & -1.303 & -2.428 & -1.653 & -2.084 \\
\hline Clothing & -0.329 & -2.414 & -2.990 & -1.665 \\
\hline Leather Products & -1.899 & -1.830 & -1.869 & -1.826 \\
\hline Footwear & -2.208 & -1.577 & -1.775 & -1.971 \\
\hline $\begin{array}{l}\text { Wood and Wood } \\
\text { Products }\end{array}$ & -0.800 & -2.824 & -1.965 & $-3.471^{*}$ \\
\hline Furniture & -2.646 & 0.667 & -2.6118 & -2.329 \\
\hline $\begin{array}{l}\text { Paper and Paper } \\
\text { Products }\end{array}$ & -2.376 & 0.219 & -3.012 & $-4.281^{* *}$ \\
\hline $\begin{array}{l}\text { Printing and } \\
\text { Publishing }\end{array}$ & 0.417 & -2.349 & -3.031 & -1.601 \\
\hline Chemical Products & $-4.036^{* *}$ & -1.295 & -1.840 & -2.515 \\
\hline Rubber Products & -1.816 & -0.025 & -1.481 & -2.263 \\
\hline Plastic Products & -2.118 & 0.213 & -2.524 & -2.079 \\
\hline $\begin{array}{l}\text { Glass and Glass } \\
\text { Products }\end{array}$ & -1.014 & -0.964 & $-3.927^{* *}$ & -2.569 \\
\hline $\begin{array}{l}\text { Other non-metallic } \\
\text { mineral }\end{array}$ & -0.813 & -2.227 & -2.697 & -1.666 \\
\hline $\begin{array}{l}\text { Iron and steel basic } \\
\text { industries }\end{array}$ & -1.517 & -0.305 & $-3.325^{*}$ & -2.866 \\
\hline $\begin{array}{l}\text { Non-ferrous metal } \\
\text { basic }\end{array}$ & -1.516 & -2.343 & -2.488 & -1.942 \\
\hline Metal Products & -0.659 & -1.606 & -2.283 & -2.088 \\
\hline Machinery & -0.558 & -1.118 & -2.488 & -2.065 \\
\hline Electrical machinery & -0.149 & 0.020 & $-3.265^{*}$ & -1.887 \\
\hline $\begin{array}{l}\text { Motor vehicles and } \\
\text { motor vehicle parts }\end{array}$ & -1.339 & -1.313 & -2.068 & -1.398 \\
\hline (an a & & & & \\
\hline
\end{tabular}

(an asterisk indicates significance at a $1 \%$ level of confidence and two asterisks at a $5 \%$ level of confidence) 
Table 3 indicates that the ADF test fail to reject the null of a unit root in both the levels and first differences of the variables for all the sectors. The failure to reject the null in first differences is problematic ${ }^{8}$, but may be due to the inability of the test statistic to perform well given the short number of observations used $(n=21)$. Following Naudé, van Heerden and van der Merwe (1997) it is assumed here that levels variables of manufacturing sub-sectors are $\sim I(1)^{9}$. Subsequent results are dependent on this assumption and further research may be required to clarify this issue. It should be noted that tests on aggregate manufacturing data spanning the period 1948 - 1995 finds the levels variable to be $\sim \mathrm{I}(\mathrm{l})$.

\subsection{Co-integration Tests}

Table 4 contain the results of the co-integration tests (using the Engle-Granger two-step methodology) between productivity and exports for the 22 manufacturing sectors.

Table 4 Cointegration Tests for Exports and Productivity

\begin{tabular}{|l|c|c|}
\hline \multicolumn{1}{|c|}{ Sector } & $\begin{array}{c}\text { ADF(4) for } \\
\text { cointegration P,X }\end{array}$ & $\begin{array}{c}\text { Cointegrated } \\
\text { (yes/no) }\end{array}$ \\
\hline Food & 0.14744 & No \\
\hline Beverages & -1.8683 & No \\
\hline Tobacco Products & -2.0932 & No \\
\hline Textiles & -0.5407 & No \\
\hline Clothing & 1.2665 & No \\
\hline Leather Products & -1.6335 & No \\
\hline Footwear & -2.1939 & No \\
\hline Wood and Wood Products & 0.1382 & No \\
\hline Furniture & -2.2216 & No \\
\hline Paper and Paper Products & -2.4365 & No \\
\hline Printing and Publishing & -0.8302 & No \\
\hline Chemical Products & -2.4144 & No \\
\hline Rubber Products & -1.2583 & No \\
\hline Plastic Products & -1.9928 & No \\
\hline Glass and Glass Products & -1.0174 & No \\
\hline Other non-metallic mineral Products & -0.2069 & No \\
\hline Iron and steel basic industries & -1.7576 & No \\
\hline
\end{tabular}


Table 4 continued

\begin{tabular}{|l|c|c|}
\hline \multicolumn{1}{|c|}{ Sector } & $\begin{array}{c}\text { ADF(4) for } \\
\text { cointegration P,X }\end{array}$ & $\begin{array}{c}\text { Cointegrated } \\
\text { (yes/no) }\end{array}$ \\
\hline Non-ferrous metal basic industries & -2.3609 & No \\
\hline Metal Products & 0.7401 & No \\
\hline Machinery & -0.5834 & No \\
\hline Electrical machinery & -2.1891 & No \\
\hline Motor vehicles and motor vehicle parts & -2.5105 & No \\
\hline
\end{tabular}

Table 4 show that no evidence of cointegration can be found between productivity and exports in South Africa's manufacturing sector. This may suggest that there exists no long-run equilibrium relationship between productivity and exports in South Africa as proposed in theory. As discussed in section 4.3 this would require the standard Granger-causality tests to be performed using first differenced variables. The results from such tests are reported in the following section.

\subsection{Granger-causality Tests}

The results from the Granger-causality test are summarised in Table 5 below with the F-test statistics from applying the relevant zero restrictions on lagged values of the respective variables as explained in section 4 above.

Table 5 Granger Causality Test for exports and Productivity Growth in South African Manufacturing, 1972-1993.

Direction of causality

\begin{tabular}{|l|c|c|}
\hline \multicolumn{1}{|c|}{ Sector } & $\begin{array}{c}\text { Exports to } \\
\text { Productivity }\end{array}$ & $\begin{array}{c}\text { Productivity to } \\
\text { Exports }\end{array}$ \\
\hline Food & $\mathrm{F}(4,9)=1.491$ & $\mathrm{~F}(4,9)=0.582$ \\
\hline Beverages & $\mathrm{F}(4,9)=0.116$ & $\mathrm{~F}(4,9)=0.365$ \\
\hline Tobacco & $\mathrm{F}(4,9)=1.133$ & $\mathrm{~F}(4,9)=2.982^{* *}$ \\
\hline Textiles & $\mathrm{F}(4,8)=0.186$ & $\mathrm{~F}(4,8)=0.514$ \\
\hline Clothing & $\mathrm{F}(4,9)=0.30$ & $\mathrm{~F}(4,9)=0.186$ \\
\hline Leather and leather products & $\mathrm{F}(4,9)=2.145$ & $\mathrm{~F}(4,9)=0.246$ \\
\hline Footwear & $\mathrm{F}(4,9)=0.914$ & $\mathrm{~F}(4,9)=0.118$ \\
\hline Wood and wood products & $\mathrm{F}(4,9)=8.107^{*}$ & $\mathrm{~F}(4,9)=1.619$ \\
\hline Furniture & $\mathrm{F}(4,9)=1.391$ & $\mathrm{~F}(4,9)=0.496$ \\
\hline Paper and paper products & $\mathrm{F}(4,9)=0.720$ & $\mathrm{~F}(4,9)=2.467$ \\
\hline Printing and publishing & $\mathrm{F}(4,8)=2.318$ & $\mathrm{~F}(4,8)=0.067$ \\
\hline
\end{tabular}


Table 5 continued

\begin{tabular}{|l|c|c|}
\hline \multicolumn{1}{|c|}{ Sector } & $\begin{array}{c}\text { Exports to } \\
\text { Productivity }\end{array}$ & $\begin{array}{c}\text { Productivity to } \\
\text { Exports }\end{array}$ \\
\hline Chemicals & $\mathrm{F}(4,8)=8.045^{*}$ & $\mathrm{~F}(4,8)=2.893^{* *}$ \\
\hline Rubber products & $\mathrm{F}(4,9)=0.591$ & $\mathrm{~F}(4,9)=0.434$ \\
\hline Plastic products & $\mathrm{F}(4,9)=0.527$ & $\mathrm{~F}(4,9)=0.205$ \\
\hline Glass and glass products & $\mathrm{F}(4,9)=1.730$ & $\mathrm{~F}(4,9)=0.485$ \\
\hline Other non-metal products & $\mathrm{F}(4,9)=1.580$ & $\mathrm{~F}(4,9)=1.701$ \\
\hline Iron and steel basic industries & $\mathrm{F}(4,9)=1.659$ & $\mathrm{~F}(4,9)=2.307$ \\
\hline Non-ferrous metal basic industries & $\mathrm{F}(4,9)=0.823$ & $\mathrm{~F}(4,9)=2.008$ \\
\hline Metal products & $\mathrm{F}(4,9)=2.406$ & $\mathrm{~F}(4,9)=5.781^{*}$ \\
\hline Machinery & $\mathrm{F}(4,9)=0.022$ & $\mathrm{~F}(4,9)=2.898^{* *}$ \\
\hline Electrical machinery & $\mathrm{F}(4,9)=0.093$ & $\mathrm{~F}(4,9)=1.901$ \\
\hline $\begin{array}{l}\text { Motor vehicles and motor vehicle } \\
\text { parts }\end{array}$ & $\mathrm{F}(4,9)=0.227$ & $\mathrm{~F}(3,9)=0.521$ \\
\hline
\end{tabular}

(Note : an asterisk indicates significance at a $5 \%$ confidence level and two asterisks at a $10 \%$ level of confidence).

Table 5 shows that there exists significant causality from productivity to exports in only four manufacturing industries, namely machinery, metal products, chemicals and tobacco. In case of chemicals, there is evidence of bi-directional causality, although the evidence seems to favour a stronger causality from exports to productivity in the case of chemicals. Table 5 indicates that there are only two manufacturing sectors where causality seems to run from exports to productivity, namely wood products and chemicals. It can be noted that Piazollo and Wurth (1992) also found that exports contributed to productivity growth in these sectors.

Generally, the results in Table 5 support the findings in Table 4, namely that little significant relationship seems to exist between productivity in exports in South Africa's manufacturing industry. To further analyse the sectors where a significant relationship seem to exist, a regression equation (equation 7) as described in section 4.4 was estimated.

\subsection{Regression Model Results}

Equation (7) was estimated for the following sectors:

- Chemicals

- Wood \& wood products

- Tobacco 
- Machinery

- Metal products

The results are summarised in Table 6 below.

Table 6 Regression Results (t-ratio in brackets)

\begin{tabular}{|l|c|c|c|c|c|c|}
\hline Sector & $\alpha_{0}$ & $\alpha_{1}$ & $\alpha_{2}$ & $\alpha_{3}$ & $\alpha_{4}$ & R-bar $^{2}$ \\
\hline Chemical & -0.022 & -0.67 & 0.224 & 0.055 & 0.938 & 0.81 \\
Products & $(-1.53)$ & $(-6.27)^{*}$ & $(2.851)^{* *}$ & $(0.451)$ & $(5.04)^{*}$ & \\
\hline Wood and & -0.021 & -0.097 & 0.139 & 0.023 & 0.675 & 0.57 \\
Wood & $(-1.877)$ & $(-0.392)$ & $(2.841)^{*}$ & $(0.337)$ & $(4.850)^{*}$ & \\
Products & & & & & & \\
\hline Tobacco & -0.057 & -0.009 & -0.065 & 0.459 & 3.226 & 0.42 \\
Products & $(-1.122)$ & $(-0.016)$ & $(-0.295)$ & $(2.265)^{*}$ & $(4.053)^{*}$ & \\
\hline Machinery & -0.022 & 0.091 & 0.022 & 0.178 & 0.575 & 0.28 \\
& $(-1.669)$ & $(0.334)$ & $(0.262)$ & $(1.213)$ & $(3.214)^{*}$ & \\
\hline Metal & -0.020 & 0.369 & 0.252 & -0.09 & 0.62 & 0.78 \\
Products & $(-2.9)^{*}$ & $(2.47)^{* *}$ & $(5.37)^{*}$ & $(-1.38)$ & $(0.64)^{*}$ & \\
\hline
\end{tabular}

Table 6 shows that in case of those sectors where it was previously established that a significant relationship existed from exports to productivity, reasonably satisfactory coefficients of determination are obtained $(0.81$ and 0.57 respectively for chemicals and wood and wood products).

In the case of chemicals, the coefficient on the capital:labour ratio $\left(\alpha_{1}\right)$ is highly significant and negative $(-0.67)$ indicating that higher capital intensity in the chemicals sector has been accompanied by a decline in MFP. The coefficient on the export:output ratio $\left(\alpha_{2}\right)$ is significant and positive $(0.224)$ indicating that a $10 \%$ increase in the export share of chemicals will raise productivity in that sector by about $2.2 \%$. The coefficient on output $\left(\alpha_{4}\right)$ is also highly significant $(0.9)$ and suggest that domestic economic growth will have a stronger effect on productivity than export growth.

The result for the wood and wood products sector and metal products is broadly similar, with a $10 \%$ increase in the export:output ratio raising productivity by about $1.4 \%$ in the wood sector and $2.5 \%$ in the metals sector. In both instances it is found that domestic output expansion has a stronger positive effect on productivity growth than exports. 
In the cases of tobacco and machinery products, it is only the expansion of domestic demand that seems to have a significant positive effect on productivity growth.

Thus, exports may have a positive and significant effect on improving productivity in two of South Africa's manufacturing sectors. However, this effect may be relatively small, and that expansion of sector output through increases in domestic demand might have larger positive effects on productivity improvements.

\section{CONCLUSION}

The direction of causality between export growth and total factor productivity growth has important implications for the way trade and industrial policies may raise productivity growth in South Africa. For instance, if causality runs from exports to productivity and to growth, then export-promotion policies such as a depreciation of the exchange rate and/or export promotion policies and tariff reduction may be sufficient. However, if there is causality from productivity to exports and growth, or bi-directional causality between exports and productivity, then R\&D and/or output subsidies may be more effective to stimulate productivity growth (Kunst \& Marin, 1989: 700).

In light of this the purpose of this paper was to determine the likely direction of causality between export growth and productivity in South African manufacturing. Due to the wide variation in the export growth and output growth rates of the various sub-sectors within manufacturing in South Africa, particularly since it may be argued that these have been due to different rates of increase in productivity, the focus in this paper was on 22 main manufacturing sub-sectors.

The results established in this paper, using conventional Granger-causality tests as well as more recent cointegration techniques, were that there exist little evidence of one-way causality from exports to productivity growth in South Africa's manufacturing sector. The only sectors for which exports may be significant in improving productivity are wood and wood products and chemical products. These results are consistent with evidence from multi-country studies by Jung and Marshall (1985) and Hutchinson and Singh (1987). It is also consistent with the findings of Piazollo and Wurth (1995) for South Africa, especially - in as far as the latter also found causality - from exports to productivity in the case of wood and chemicals. According to Kohler and Holden (1992: 36) a possible explanation for the lack of causality between productivity and exports in South Africa's manufacturing sector could be that 
productivity (especially labour productivity) and labour compensation are highly and positively correlated over time - i.e. industries with high levels of labour productivity also have relatively high labour costs.

Furthermore, it was established that although export expansion will positively affect productivity growth in two sectors of manufacturing, these effects are relatively small, having an elasticity of 0.22 and 0.13 respectively in case of chemicals and wood and wood products. In addition, these effects are exceeded by the positive effect of output expansion through domestic demand increases on productivity.

The shortcomings of the methodologies employed in this paper caution against drawing policy recommendation from these results. Although, as stressed above, the results are broadly consistent with international and local findings, the poor quantity and quality of manufacturing sub-sector data in South Africa would require that the issue remain on the research agenda. Until further and better time-series data becomes available, firm-level studies, such as those by Valodia (1998) for instance, may be the best way to investigate the direction of causality between export growth and productivity over the short-term.

\section{ENDNOTES}

1 An earlier version of this paper was presented at the Annual TIPS Forum, 20 September 1998 at Glenburg Lodge, Johannesburg. The authors are grateful to Prof Wilma Viviers for comments and advice and also to various participants at the Forum, particularly Prof Johannes Fedderke. The financial assistance of the Research Focus Area "Decisionmaking and Management for Economic Development" of the Faculty of Economic \& Management Sciences, Potchefstroom University, is hereby acknowledged. The usual disclaimer applies.

2 For instance Jung and Marshall (1985) found no relationship between exports and growth in the Philippines but found such a relationship in the case of Thailand. Hsiao (1987) found a positive relationship for Hong Kong but not for the other newly industrialised countries (NICs).

A reasons why time-series studies into the causal direction between exports and growth find mixed results may be that the causal models estimated in these studies are misspecified - by not adequately incorporating the time lag between higher export growth and higher output growth that occurs via higher total factor productivity.

$4 \quad$ David Ricardo set out his doctrine of comparative costs in his "Principles of Political Economy" in 1817. 
5 Teitel and Thoumi (1986: 466) claim that, with reference to Brazil and Argentina, that "Substantial increases in domestic output provided the opportunity to accumulate operating knowledge and to improve the efficiency of production until domestic costs have become comparable to the international ones. In this way, exports also become possible, albeit sometimes requiring a measure of government support".

6 By 'stationary' is meant that the first two moments of the data are invariant with respect to time.

7 By 'stationarity' is meant that the first two moments of the data are invariant with respect to time.

Nelson and Plosser (1982) have found that most macroeconomic variables have a univariate time series structure with a unit root.

Perron (1994: 116) argues that standard unit root tests such as the ADF tests are biased towards non-rejection of the unit root null hypothesis if the data are characterised by stationary fluctuations around a trend function that exhibits a structural change.

\section{REFERENCES}

1. ABEYSINGHE, T. \& YEOK, T.L. (1998) "Exchange Rate Appreciation and Export Competitiveness: the Case of Singapore", Applied Economics, 30: $51-5$.

2. AKAIKE, H. (1981) "Likelihood of a Model and Information Criteria", Journal of Econometrics, 16: 3-14.

3. BANERJEE, A., DOLADO, J., GALBRAITH, J.W. and HENDRY, D.F. (1993) Co-Integration, Error-Correction, and the Econometric Analysis of Non-Stationary Data, Oxford: Oxford University Press.

4. BELL, T. \& CATTANEO, N. (1998) "Foreign Trade and Employment in South African Manufacturing Industry", Occasional Report no. 4, Employment and Training Department: International Labour Office, Geneva.

5. BHAGWATI, J.N. (1978) Foreign Trade Regimes and Economic Development: Anatomy and Consequences of Exchange Control Regimes, Cambridge: Ballinger.

6. CHAND, S. (1998) "Trade and Endogenous Growth with Ricardo-Viner Production Technology", The Economic Record, 74(224): 15-23.

7. CHOW, P.C.Y. (1987) "Causality Between Export Growth and Industrial Performance: Empirical Evidence from the NICs", Journal of Development Economics, 26: 53-63.

8. COETZEE, Z.R., NAUDÉ, W.A. and GWARADA, K. (1997) "Currency Depreciation, Trade Liberalisation and Economic Development", South African Joumal of Economics, 65 (2): 165-190. 
9. DICKEY, D.A. \& FULLER, W.A. (1981) "Likelihood Ration Statistics for Autoregressive Time Series with a Unit Root", Econometrica, 49: 1057-72.

10. EMERY, R.F. (1967) "The Relation of Exports and Economic Growth", Kyklos, 20: 470-86.

11. ENGLE, R.F. \& GRANGER, C. (1987) "Dynamic Model Specification with Equilibrium constraints: Cointegration and Error-Correction", Econometrica, 55: 251-76.

12. FAJANA, O. (1979) "Trade and Growth: the Nigerian Experience", World Development, 7(1): 73-8.

13. GEAR (1996) "Growth, Employment and Redistribution: A MacroEconomic Strategy", Department of Finance, Pretoria.

14. GEROSKI, P.A. (1989) "Entry, Innovation and Productivity Growth", Review of Economics and Statistics, 71(4): 555-78.

15. GONCALVES, R. \& RICHTERING, J. (1987) "Intercountry Comparison of Export Performance and Output Growth", The Developing Economies, 25: 3-18.

16. GRANGER, C.W.J. (1969) "Investigating Causal Relations by Econometric Methods and Cross Spectral Methods", Econometrica, 37: 428-38.

17. GRANGER, C.W.J. (1986) "Developments in the Study of Co-Integrated Economic Variables", Oxford Bulletin of Economics \& Statistics, 37: 42838.

18. GROSSMAN, G.M. \& HELPMAN, E. (1990) "Trade, Innovation and Growth", American Economic Review, 80: 86-91.

19. HARBERLER, G. (1937) The Theory of Comparative Cost, London: MacMillan.

20. HARRIS, R. (1995) Using Cointegration Analysis in Econometric Modelling. London: Prentice-Hall/Harvester Wheatsheaf.

21. HELPMAN, E. \& KRUGMAN, P. (1989) Trade Policy and Market Structure, Cambridge MA: MIT Press.

22. HSIAO, M.C.W. (1987) "Tests of Causality and Exogenity Between Exports and Economic Growth: The Case of Asian NICs", Journal of Economic Development, 12: 143-59.

23. HUTCHINSON, M. \& SINGH, N. (1987) "Exports and Growth in Developing Economies: Identifying Externality Effects", Working Paper, University of California, Santa Cruz.

24. ISLAM, M.N. (1998) "Export Expansion and Economic Growth: Testing for Cointegration and Causality", Applied Economics, 30: 415-25.

25. ISCAN, T. (1998) "Trade Liberalisation and Productivity: A Panel Study of the Mexican Manufacturing Industry", Journal of Development Studies, 34(5): 123-48. 
26. JOHANSEN, S. (1988) "Statistical Analysis of Cointegrating Vectors", Journal of Economic Dynamics and Control, 12: 231-54.

27. JUDGE, G.G., Hill, R.C., GRIFFITHS, W.E., LUTKEPOHL, H. and LEE, T.C. (1988) Introduction to the Theory and Practice of Econometrics. $2^{\text {nd }}$ ed., New York: Wiley \& Sons.

28. JUNG, W.S. \& MARSHALL, P.S. (1985). "Export Growth and Causality in Developing Countries", Journal of Development Economics, 14: 24150.

29. KALULUMIA, P. \& YOUROUGOU, P. (1998) "Money and Income Causality in Developing Countries: A Case Study of Selected Countries in Sub-Saharan Africa", Journal of African Economies, 6(2): 197-231.

30. KAVOUSSI, R.M. (1984) "Export Expansion and Economic Growth: Further Empirical Evidence", Journal of Development Economics, 13: 112.

31. KOHLER, M. \& HOLDEN, M.G. (1992) "Competitive Cost Advantage and South African Trade Performance in Manufacturing Industry", In Van Pletsen, J.L. \& Hurter, J. eds., Industrial Policy \& Development in South Africa, Vol 1, March, Sandton: IDC.

32. KRUGMAN, P. (1984) "Import Protection as Export Promotion" (In Kierzkowski, H. ed., Monopolistic Competition in International Trade. Oxford: Oxford University Press.)

33. KUNST, R.M. \& MARIN, D. (1989) "On Exports and Productivity : A Causal Analysis", Review of Economics \& Statistics, 62(4): 699-703.

34. LEVINE, R. \& RENELT, D. (1992) "A Sensitivity Analysis of CrossCountry Growth Regressions", American Economic Review, 82: 942-63.

35. LUCAS, R.E. (1988) "On the Mechanics of Economic Development", Joumal of Monetary Economics, 22: 3-42.

36. LUCAS, R.E. (1990) "Why Doesn't Capital Flow from Rich to Poor countries?", American Economic Review, 80: 92-6.

37. MACKINNON, J.G. (1991) "Critical Values for Cointegration Tests", In Engle, R.F. \& Granger, C.W.J. eds., Long-Run Economic Relationships. Oxford : Oxford University Press.

38. MILLER, S.M. \& RUSSEK, F.S. (1990) "Co-Integration and ErrorCorrection Models: the Temporal Causality Between Government Taxes and Spending", Southern Economic Journal, 56: 221-9.

39. NAUDE, W.A. (1992) "The Appropriate Intermediate Target for Monetary Policy in less Developed Countries: Empirical Evidence", Development Southern Africa, 9(2): 121-37.

40. NAUDÉ, W.A. (1996) "Enabling Entrepreneurs to Export: An .Argument for Effective Education", Southern African Journal for Entrepreneurship and Small Business, 8(1): 9-22. 
41. NELSON, C.R. \& PLOSSER, C.I. (1982) "Trends and Random Walks in Macro-Economic Time Series: Some Evidence and Implications", Journal of Monetary Economics, 10: 139-62.

42. OKUDA, S. (1997) "Industrialisation Policies of Korea and Taiwan and their Effects on Manufacturing Productivity", The Developing Economies, 35(4): 358-81.

43. PERRON, P. (1994) "Trend, Unit Root and Structural Change in Macroeconomic Time Series", In Rao, B. ed., Cointegration for the Applied Economist. London: MacMillan.

44. PIAZOLO, M. \& WURTH, M. (1992) "Determinants of Productivity Growth: The Case of South African Manufacturing Industries", In Van Pletsen, J.L. \& Hurter, J. eds., Industrial Policy \& Development in South Africa-volume 2, September. Sandton : IDC.

45. PIAZOLO, M. \& WURTH, M. (1995) "Productivity in the South African Manufacturing Industry : a Cointegration Appproach", South African Journal of Economics, 63(2): 173-98.

46. RODRIK, D. (1988) "Closing the Technology Gap: Does Trade Liberalisation Really Help?", mimeo : Harvard University.

47. ROMER, P.M. (1986) "Increasing Retums and Long-Run Growth", Journal of Political Economy, 94: 1002-37.

48. ROMER, P.M. (1990) "Are Noncovexities Important for Understanding Growth?", American Economic Review, 80: 97-103.

49. TEITEL, S. \& THOUMI, F.E. (1986) "From Import Substitution to Exports: the Manufacturing Exports Experience of Argentina and Brazil", Economic Development and Cultural Change, 34: 455-90.

50. VALODIA, I. (1998) "Trade Policy, Productivity \& Learning: Evidence in South Africa", TIPS Working Paper No. 10, Johannesburg.

51. YADAVALLI, L. (1998b) "We're Doing Better", Productivity SA, July/Aug: 7 - 9. 